\title{
Comparative review of foam formation in biogas plants and ruminant bloat
}

\author{
Lucie Moeller $^{1 *}$, Kati Goersch ${ }^{1}$, Juergen Neuhaus² ${ }^{2}$ Andreas Zehnsdorf ${ }^{1}$ and Roland Arno Mueller ${ }^{1}$
}

\begin{abstract}
This review gives an overview of the current knowledge concerning the problem of foam formation in the process of anaerobic digestion in biogas plants that utilize renewable resources or biogenic waste material for biogas production. Process upsets in biogas production induced by foam formation can have a negative impact on the efficiency of biogas plants. The foam can block gas pipes and cause severe damage to the bioreactor equipment, ranging from a failure of the feeders to a damage of the roof of the biogas plant. The most common foam removal methods - stirring in the foam, adding anti-foaming agents, diminishing substrate feeding, and altering the biogas reactor management - are not always successful. However, the reasons for the excessive foam formation during the biogas production process have not yet been elucidated in detail. In contrast, foam building in the rumen of ruminants as a cause for bloat has been studied thoroughly. In general, the interaction between proteins, polysaccharides (mucilage), and small plant particles is assumed to be the crucial factor. As the fermentation process in the rumen has many similarities with the biogas production process, the current research results on bloat in ruminants are summarized and compared with the process of foaming in biogas plants.
\end{abstract}

Keywords: Foam formation, Biogas plants, Renewable resources, Biological wastes, Causes, Treatment, Prevention, Bloat

\section{Review Introduction}

In order to achieve a sustainable energy production, a great number of biogas plants have been commissioned in Germany in the last decade. In late 1999, a total of 850 biogas plants were registered with a capacity of 49 MWel [1], whereas 12 years later, in November 2011, about 7,100 biogas plants (with an installed power of 2,780 MWel) were counted by the Fachverband Biogas e.V. (Freising, Germany) [2]. Since biogas production is independent of weather conditions and diurnal cycles, it is a very attractive component in the mixture of renewable energy sources. The potential of this type of energy production from biomass is huge. Nevertheless, some problems still occur during the biogas production process that can have serious consequences for the biogas plant operator. In addition, the causes of these problems are only partly understood or not understood at

\footnotetext{
* Correspondence: lucie.moeller@ufz.de

${ }^{1}$ Environmental and Biotechnology Centre, UFZ - Helmholtz Centre for Environmental Research, Permoserstrasse 15, Leipzig 04318, Germany Full list of author information is available at the end of the article
}

all. One of these problems is the excessive formation of foam within the biogas reactor. A survey of waste treating biogas plants in north-eastern Germany showed that twelve out of fifteen biogas producers reported foam formation in their biogas reactors [3]. This problem also concerns biogas plants which use renewable resources for biogas production: another survey of agricultural biogas plants in Mecklenburg-West Pomerania showed that foam formation is considered to be one of the most frequent disturbances in biogas reactors [4].

Although this phenomenon appears in a very high percentage of biogas plants, little research has been carried out so far on this topic. Most publications deal with the problem of foam production during the anaerobic stabilization of activated sludge [5-14]. In this review, the current knowledge regarding foam formation in biogas plants, which are processing renewable resources or biogenic waste material, has been summarized for the first time. In order to explain the characteristics of foam formation, knowledge from other scientific fields such as biotechnology, veterinary medicine, and food science is also presented. 


\section{What is foam?}

Foam is generally a dispersion of a gas in a liquid consisting of a large proportion (approximately 95\%) of gas. The liquid phase is located in a thin film which is present between the gas bubbles [15]. However, foam can be produced only after a certain threshold concentration of a surface-active compound has been exceeded. Surface-active compounds have amphiphilic properties, i.e., their molecules obtain both hydrophilic and hydrophobic functional groups. In low concentrations, surface-active compounds behave innocuously. Some of their physical properties, such as the surface activity, change abruptly when a certain concentration is exceeded (the so-called critical micelle concentration). These compounds then build clusters (micelles) in solutions and monomolecular layers on surfaces [15].

The formed foam is further stabilized, e.g., by carbohydrates and proteins [16] or by suspended particles [13], thus, resulting in a three-phase system. From other biotechnological fields, it is known that foam production in submerse cultures is dependent on the hydrodynamic conditions which are in turn affected by gas production, medium composition, the presence of growing cells, and the production of metabolites and surface-active compounds [17]. The produced foam and the stabilizing compounds can be released by both cell metabolism as extracellular products (e.g., exoenzymes) and by enzymatic decomposition after cell autolysis. Moreover, the cell surface itself can have hydrophobic properties - some microorganisms produce extracellular polymeric substances which enable the cells to hold onto each other or to stick to surfaces (e.g., biofilm formation). Through the effect of physical processes, such as stirring, the cell walls are exposed to shear stress, which leads to the release of substances with surface-active properties [12,17]. Substances supporting foam formation and stabilizing the foam also enter the biogas reactor during its feeding procedure.

\section{Foam formation in biogas plants}

According to biogas plant operators, there are two types of foam in biogas plants, which differ in size and in terms of the difficulty of eliminating them [3]. Foam with a relatively large bubble diameter is easy to combat by diet or starvation and by the use of stirrers. In contrast, foam with small bubbles causes more difficulties as it is very stable and not easy to remove. More detailed information on the chemical properties of these foams as well as the mechanism of their formation is not yet available.

\section{Causes of foam in biogas plants}

The process of foam formation in biogas plants is very complex. Due to the complexity of biosystems, it is difficult to relate their foaming characteristics to single medium components [17]. Nevertheless, some correlations between foaming and feeding of certain substrates and other incidences in biogas reactors can be observed.

Surface-active compounds are a broad substrate group that is closely related to foam formation. There are two groups of surface-active compounds which are relevant for the problem of foam formation in biogas plants: surfactants and biosurfactants [13]. Surfactants are compounds such as volatile fatty acids, oil, grease, detergents, and proteins which enter the biogas reactor with the feed streams. Biosurfactants are natural substances that are products of microbial activity inside the digester [13]. They can be divided into six classes: hydroxylated and cross-linked fatty acids (mycolic acids), glycolipids, lipopolysaccharides, lipoproteins-lipopeptides, phospholipids, and the complete cell surface itself [18]. Biosurfactants, which are responsible for both the cohesion of microbial cells forming granules and the adhesion of microbial cells on the surfaces, are also called extracellular polymeric substances [12,13,19].

Volatile fatty acids (VFA), as intermediates of the methane production process, are always present in the biogas reactor and are constantly formed and degraded. As the methanogenic stage of biogas production is the ratelimiting step, disturbance of the anaerobic digestion process can cause an accumulation of secreted VFAs which cannot be transformed any further $[8,20]$. As has been reported by Ross and Ellis [6] and Westlund et al. [8], the presence of VFAs in biogas sludge is associated with foam formation. However, it is not clear whether the increased concentration of VFAs is the cause or the consequence of excessive foaming [6].

Lipids also influence the foaming potential of biogas sludge to a certain degree. Due to their hydrophobic characteristics, lipids tend to diffuse to the surface. They settle there and contribute to foam formation by decreasing the surface tension [21,22]. In anaerobic digesters, lipids occur mostly in the form of oil and grease [13]. They are easily hydrolyzed into their components, fatty acids and glycerol, which are subsequently converted to biogas. The foaming potential of lipids only becomes a problem in biogas plants if there are other unfavorable circumstances [3]: in one waste-treating biogas plant, the combination of sudden temperature change and feeding of contents of grease separators led to major foam generation. Laboratory tests showed increased concentrations of oleic acid in the foam compared to the biogas sludge (L Moeller, unpublished results).

Detergents are another group of surfactants. They can enter the biogas reactor as components of industrial wastewater from breweries, dairies, and paper and textile industries [13].

Proteins play a crucial role in foam formation. They occur in biogas plants as a consequence of both feeding and microbial activity. Protein-rich substrates are, for example, clover, poultry manure [23], and slaughter wastes 
[3]. Proteins contain high amounts of nitrogen that is present in organic matter and is bound in the form of amino groups. In the course of decomposition, ammonium is released, which is in dissociation equilibrium with ammonia - a strong cell poison. The shift in equilibrium in the direction of ammonia can be caused by factors such as temperature increase or changes of $\mathrm{pH}$ within the biogas reactor [23].

Moreover, there is a clear relationship between high nitrogen concentrations in the fermentation sludge and excessive foam formation. Apart from poultry excrements, other farm manures also contain higher amounts of nitrogen in the form of ammonium, proteins, and urea than what microbes can convert for their cell growth. This residual ammonium can inhibit the anaerobic digestion process provided it appears in the form of ammonia $[19,24]$. For this reason, farm manure should be mixed with materials of low nitrogen content before feeding. The accumulation of ammonium can also be the consequence of re-feeding one part of the digestate in order to mash the substrates with high dry matter contents. In that case, the increase in the concentration of nitrogen compounds is the consequence of a continual return of digested contents to the process [4].

Although the metabolic products of protein decomposition are responsible for extensive foaming, the proteins themselves also serve as foam stabilizing agents, as has been described for the production of milk foam [21]. Flexible proteins (e.g., $\beta$-casein) diffuse to the surface where they unfold, presumably because the protein concentration is sufficiently low there, and it is enough space for the molecules to spread. Due to the dissemination of proteins on the surface as a consequence of structural changes, the gas bubble is stabilized. In contrast, large globular protein molecules unfold very slowly and, thus, produce foam of lower volumes and with smaller but more stable bubbles [21]. At temperatures above $40{ }^{\circ} \mathrm{C}$, the superhelical protein structures disappear, and there are only $\alpha$-helix and knotted structures in the solution in equilibrium. As in the case of denatured proteins, the knotted structure is unordered and surface active [15].

Immoderate feeding of easily degradable substrates such as fruit and vegetable wastes, as well as sugar beet chips is often accompanied by foam formation $[3,19]$. These substrates contain mostly mono- or oligosaccharides, which were rapidly hydrolyzed to propionic and butyric acid through fermentation pathways of the microorganisms [23]. In consequence, there is a danger of acidification due to the excess supply of VFAs as degradation intermediates of saccharides. These compounds cannot be converted any further and accumulate in the biogas sludge. Acidification is sometimes accompanied by excessive foam formation, as described in Baserga [25]. Thus, it is recommendable to feed easily degradable substrates more frequently in smaller batches or in the substrate mixture with other suitable raw materials high in nitrogen $[19,23,26]$.

The application of rye groat for biogas production is also accompanied by foam formation [3]. The functional mechanism of foam formation caused by this substrate is not yet clear. Meuser et al. [27] studied the foam-forming capacity of substances in rye milling products used in rye crispbread production. The authors attribute the foam-inducing properties of rye to the presence of a 'relatively homogeneous water-soluble protein'. According to their observation, other components have either foam-stabilizing (in the case of fructosans) or destabilizing (pentosans) effects. Zehle [28] conducted microscopical observations of rye-based foams in the manufacture of bakery products and identified starch as the foam-stabilizing substance. Zehle [28] observed that the foam-forming and -stabilizing effects are influenced by the fineness of the ground rye products.

Excessive foaming in the anaerobic stabilization of waste-activated sludge is commonly connected with the presence of filamentous microorganisms (e.g., Microthrix parvicella, Nocardia spp.). Since this topic has been discussed in detail in the literature [5,7,8,11-13], it is not included in this review. So far, there has been no indication of any connection between extensive foam formation and filamentous bacteria utilizing renewable resources or biogenic wastes in biogas plants.

Foam formation also occurs as a consequence of inadequate plant management. Oelsner [29] stated that excessive loading rates of more than $4 \mathrm{~kg} o D M \cdot \mathrm{m}^{-3} \cdot \mathrm{d}^{-1}$ can lead to continuous foam formation. Feeding of high charges at low frequencies causes an accumulation of degradation products and by-products. The biogas plant is overloaded, and the probability of excessive foam formation is high $[6,13,25]$.

Increased attention is also required for the use of spoiled silages. Effenberger et al. [30] advised against the use of badly prepared silage. Due to the missing or insufficient covering of silage, mycotoxins (metabolic products of moulds, such as Fusarium) are produced in the silage. These compounds can inhibit the microorganisms and, thus, lead to excessive foam formation [30].

The likelihood of excessive foaming in a biogas plant can also be connected with technological attributes such as unsuitable heating and agitating devices. An incorrectly dimensioned heating system leads to insufficient heat transfer and, in combination with inadequate agitation, finally to foam formation [31]. In contrast, excessive mixing causes process imbalances due to the disturbance of microbial aggregates and can also lead to foam formation due to the agitation of sediments [32]. Thus, the choice of the agitation system is of importance for the foam potential of the biogas plant. Pagilla et al. [7] tested two agitation systems: a mechanically mixed and a gas-mixed anaerobic 
digester. The authors found that mechanically mixed systems have a lower susceptibility to foam formation than gas-mixed digesters.

\section{Consequences of excessive foaming in biogas plants}

Foam formation can cause various operational disturbances and severe damage to equipment, such as the encrustation of reactor walls, failures of feeders and recirculation pumps, contamination of gas and condensate pipes, and failures of measuring sensors, and, thus, problems in process control $[7,13]$. The blockage of gas pipes can cause an increased pressure within the biogas reactor, which activates the pressure control valve, thus, leading to additional safety problems.

As a consequence of the presence of stable foam within the biogas reactor, the usable bioreactor volume and digestion time reduce, the mixing state of the reactor worsens, the degree of degradation decreases and, as a result, the biogas yield drops $[12,13]$. The profile of solid matter can invert, meaning that higher solid concentrations occur in the upper part of the biogas reactor and dead zones can form $[7,13]$.

The costs related to foam incidents differ depending on the seriousness of the event. They include loss of gas yield, costs for anti-foaming agents, surplus working hours, and purification expenses $[7,8,10]$. Foam protection requires additional plant components and measuring equipment (e.g., foam sensors, foam traps, and dosing apparatus for anti-foaming agents inside the fermenter, as well as a foam outlet in the subsequent stages of sludge storage [29,31]). These precautions imply higher investment costs. However, if uncontrolled foaming causes immense damage to the biogas reactor equipment, the total costs can be much higher, as described by Moeller et al. [3]: excessive foam formation in one waste-based plant in Saxony led to the damage of the roof of the biogas reactor. The operator estimated the total damage amounting to $€ 500,000$.

\section{Foam suppression}

Foam suppression should already be considered in the planning stage of a biogas plant. Various engineering measures can be used to prevent excessive foaming or to help destroying the foam. For example, rotating components can be installed that apply shear forces to the foam formed. Westlund et al. [9] tested a mixer installed above the biogas sludge level in the foam phase close to the gas outlet in order to prevent the blocking of gas tubes by foam residues. The authors achieved a very good foam removal with this solution.

Moreover, reactor parts that impair the movement of the medium and cause currents and turbulence at the surface of the reactor should be avoided [33]. Biogas plant operators also advise to equip the biogas plant with a container for collecting rainwater which can be used for diluting the foaming mass [3].

When the biogas plant has been built, the biogas production process begins gradually. Foam formation is a common occurrence during this starting period [33]. The stage of process stabilization can take up to 1.5 years ( $\mathrm{R}$ Winterberg, personal communication). It is very important to allow enough time for this process so that the microbial community can adapt in order to avoid process imbalances [3]. It is also recommended to use biogas sludge from another stable biogas reactor as an inoculum during the starting phase.

If foam is formed during the running biogas production process, several measures can be implemented to avoid greater damage due to uncontrolled foaming. Moeller et al. [3] summarized the experiences of biogas plant operators using various methods in their fight against foam in the biogas reactor. The preferred method was a strict diet for 2 to 3 days (also called 'starvation diet') in order to allow the microbial community to convalesce and to adapt to new conditions. In some cases, part of the biogas reactor content was pumped out to allow the agitators to stir the foam. Moreover, the foaming mass was then diluted with water. It is advisable to check the operation policies, such as the stirring cycle and the feeding regime, since finding the optimum process management could considerably contribute to a stabilization of the microbial community within the biogas reactor. As every biogas plant differs both in its construction features and its microbial community, no exact rules can be stated. It is generally recommended to feed as often as possible, especially if there are easily degradable substrates in the substrate mixture [34]. The stirring period should not be too long to protect the microbial agglomerates but also not too short to prevent the formation of floating layers.

Several methods have been developed for the case, where filamentous microorganisms, such as M. parvicella, are responsible for foam stabilization in digesters treating activated sludge. One of the most effective technologies is the pretreatment of sludge using ultrasound [35]. The principle here is to split or damage the microbial filaments. Moreover, ultrasonic pretreatment enables the disintegration of hardly degradable structural materials so that they are available for microbial conversion [13].

The application of anti-foaming agents represents a chemical method of foam removal. The principle of antifoaming agents is based on the destruction of foam by replacing the foam-inducing surface film with a completely different type of film by substituting all of the foam stabilizing substances. Therefore, the surface tension of anti-foaming agents has to be low enough to allow them to spontaneously spread out over the film [15]. The most commonly used anti-foaming agent is plant oil. The advantages of plant oils as a defoamer are their 
biodegradability, good availability, and low price [17]. However, only those oils where mucilage, such as phosphoglycerides, has been removed should be used [3]. There are several other chemical defoamers in the market with varying degrees of effectiveness with respect to foam destruction. It is important to be careful when choosing an anti-foaming agent because it is not advisable to use chemicals containing siloxane. These compounds are volatile and can cause abrasion in engines during the combustion of biogas due to silicium depositions [36]. Before applying an anti-foaming agent, economic aspects, such as the amounts required and the efficiency of foam removal, should be evaluated. The choice of an appropriate concentration is very important as too low or too high concentrations can contribute to a stabilization of the existing foam [17]. Moreover, excessive amounts can have a negative impact on the biogas microbiology (L Moeller, unpublished results).

However, the target here is to prevent foam formation by careful handling. In his instructions for good biogas practice, Baumann [34] stated: 'Only those biogas plant operators who regard the biogas reactor as a large round cow will be successful.'

\section{Frothy bloat in ruminants and consequences for biogas foam research}

Just as in biogas plants, gas in the rumen of ruminants is produced as a natural by-product of both digestive fermentation and acidification of bicarbonate [37]. This gas contains approximately $20 \%$ to $30 \%$ methane, $45 \%$ to $70 \%$ carbon dioxide, and trace amounts of nitrogen, oxygen, hydrogen, and hydrogen sulfide [37,38]. In order to remove this gas, the animals belch about once every minute [39]. If the gas release is disturbed, foam forms in the digesta. This phenomenon is common; the foam is predominantly of low persistence and occurs only in small amounts. In contrast, the formation of large amounts of rigid foam of a high persistence is problematic [37]. This so-called bloat is a common disorder in cattle and is characterized by the prevention of a release of the fermentation gases from the content of the first two compartments of the ruminant's stomach (rumen and reticulum) [40]. Thus, the gas cannot be expelled by belching [41]. This can proceed rapidly and may lead to the ultimate death of the affected animals, which usually follows from internal pressure on the vital organs (i.e., heart and lungs) lying close to the rumen $[42,43]$. The main problem of this complex disease is its rapid progress and the difficulty of predicting its occurrence under field conditions [44]. The complexity results from the interaction of plant, animal, and microbial factors which lead to foam formation [37].

A lot of research has been conducted in this area compared to the research regarding foam formation in biogas reactors due to the severe economic consequences of this phenomenon. The estimated average loss per year due to bloat is $\$ 180$ million in Australia and $\$ 310$ million in the USA [43]. For this reason, several reviews about this topic have been published up to now $[37,38,40,44,45]$.

\section{Classification of ruminant bloat and its causes}

In general, there are two types of bloat in ruminants: freegas bloat and frothy bloat [44]. Causes for free-gas bloat (also known as dry bloat) can be irregular food intake, inhibition of the nerves controlling the contractions of the rumen walls, and physical obstruction of the esophagus, e.g., from swallowing plastic bags (common in goats) $[39,44]$. Free-gas bloat is more sporadic than frothy bloat accounting for only approximately $10 \%$ of cases and affecting only few animals [44]. Nevertheless, this kind of bloat is well-known for its rapid progress and high mortality [40]. As this kind of bloat is not comparable to foam formation in the biogas reactor, it will not be described in detail. In contrast, frothy bloat in the rumen is very similar to a foaming biogas fermenter.

Frothy bloat is usually further classified into two types: pasture bloat and feedlot bloat [40,44]. Pasture bloat predominates in animals grazing fresh forage legumes, especially in spring $[43,45]$, and has an acute character. Maximum foaminess of the rumen content occurs 1 to $2 \mathrm{~h}$ after the cow begins eating bloat-causing forage and is reduced to the pre-feeding level $4 \mathrm{~h}$ later [46]. Feedlot bloat occurs rather infrequently, mainly in cattle fed diets that are high in grain and low in roughage $[40,44,45]$. Most cases of feedlot bloat are sub-acute or chronic, occurring mainly after the cattle has been on feed for about 14 days $[40,44]$.

The cause of pasture bloat is the grazing of inadequate plants, i.e., mainly alfalfa (Medicago sativa), various clovers (Trifolium spp.) and wheat (Triticum spp.), and to a minor degree succulent grasses, various crops such as cereals and brassicas, and hay $[37,40]$. The ability to induce foam formation results from their chemical composition. Plant proteins, saponins, pectins, hemicelluloses, bacterial polysaccharides, and peptide slimes - either solely or acting in combinations - have all been considered responsible for the formation of stable foams [42,46]. However, foam stability is probably also affected by traces of metal hydroxides and, in some cases, metal cations (nickel and zinc) [42]. Bloat is also associated with high levels of potassium and low levels of sodium in the rumen [47].

Several theories about the process of foam formation in the rumen are presented in the literature. The traditional theory is based on the influence of soluble proteins (produced from legume forage in the rumen fluid) on foam stabilization $[37,44]$. In particular, two proteins, known as Fraction I protein (or 18 S) [37] and Fraction II protein [48], are considered to have a crucial role in foam stabilization. These proteins are released by the destruction of chloroplasts during the digestion process. After leaving 
the plant cell, they are dissolved in the rumen fluid as almost spherical particles. When they reach the liquid surface, they uncoil and become insoluble [37]. Only this surface-denatured form of the protein possesses the foamstabilizing effect. This supports the role of metal ions as contributing factors to foam formation as they precipitate proteins by binding [40].

The current theory is essentially an extension of the first theory, which has been published by Howarth et al. [49]. In addition to the release and surface denaturation of soluble proteins, according to this theory, there are two more factors involved in foam stabilization. Both small plant particles and foam-stabilizing polycarbonates (polysaccharides) play a crucial role in the process of ruminant foam formation $[44,49]$. Fine plant particles originate from decomposed chloroplasts; their presence in the rumen fluid facilitates gas bubble coalescence, thus, leading to an obstruction to the release of fermentation gases [49]. Exopolysaccharides are produced by ruminant bacteria and contribute to the stabilization of foam to a substantial degree. If there are optimum conditions for the proliferation of the microorganisms, the production of polysaccharides occurs at a high rate [40]. Exopolysaccharides are highmolecular polymeric compounds excreted by the microorganisms into the medium and serve mostly as a cell protection in the form of bacterial slimes. Majak et al. [44] also include internal polymeric substances (e.g., storage granules) in the category of foam-stabilizing polycarbonates. Moreover, all these substances significantly influence the viscosity of the rumen liquid. An increase of viscosity due to the rapid cell lyses and the release of proteins from plant cells is a substantial factor in pasture bloat genesis [48]. Thus, the bloat potential of crops depends on their digestibility by rumen bacteria [44]. The easier the substrates are decomposed, the higher is the risk of frothy bloat. Fragile plants with thin cell walls have a higher probability to cause pasture bloat than plants with thicker cell walls and veins [44]. The effect of easy digestibility on the rumen microbes can be demonstrated by one example from Majak et al. [44]: 'When steers are fed fresh alfalfa, they produce up to $2 \mathrm{~L}$ of gas per minute.'

Apart from proteins, there are a few other compounds which are involved in the development of pasture bloat to varying degrees. Saponins, which occur in significant amounts in both alfalfa and clover, are known to form stable foams already at very low concentrations [50]. Lindahl et al. [51] performed an experiment with various ruminants which were fed with alfalfa saponin solution. They found that the presence of this compound leads to foam formation in the rumen. On the other hand, Clarke and Reid [37] claimed that saponins have a minor effect on foam stability in the rumen fluid.

In contrast to saponins, pectins are not primary foaming agents. However, they still have an influence on foam stabilization due to their contribution to the enhancement of the viscosity of rumen fluid after their demethylation through the action of the ubiquitous enzyme 'pectin methylesterase' [37].

It is not easy or may be impossible to identify the role of single rumen components in bloat genesis. Howarth et al. [48] state: 'It is probably unreasonable to expect that a single plant constituent is highly correlated with bloat. There are other surface-active plant constituents, such as saponins and polar lipids, which are undoubtedly a part of the frothy complex, either as foaming agents or as anti-foaming agents. A persistent foam probably occurs, when the critical concentration of several surface-active agents occur in vivo.'

In addition to the plant characteristics, the animal's susceptibility to bloating plays a certain role. In general, greedy feeders have a higher probability to bloat than poor feeders [38]. In New Zealand, cattle are classified into the two categories of having high and low susceptibility to bloat [40]. There are also differences between ruminants in general. Colvin and Backus [45] stated that one alfalfa pasture grazed by sheep and cattle caused serious bloat in cattle but had little effect on sheep.

Moreover, there are further aspects in pasture bloat etiology. The probability of bloat increases when grazing immature, frozen, or wet grasses (e.g., due to the morning dew) as well as at the beginning of the rainy season when ruminants are exposed to fast growing lush pasture [39,52].

In contrast, frothy feedlot bloat occurs most commonly when cattle are fed on diets containing high proportions of grain and insufficient amounts of roughage [40]. The causes of feedlot bloat are comprehensively described in Majak et al. [44]: The finely ground grain contains small particles which are responsible for both foam formation and stabilization in the rumen. Fine grinding of grain provides a larger surface for microbial settlement in the rumen and, in consequence, supports bacterial proliferation, similar to the role of easily digestible substrates in pasture bloat. Thus, a lot of microorganisms synthesize high amounts of polymeric substances (mainly polysaccharides) such as extracellular slime and intracellular storage compounds which are released after cell rupture due to the increasing rumen osmolarity [40]. These substances enhance the viscosity and frothiness of the rumen fluid. On the other hand, fine particles themselves are able to stabilize foam. These circumstances should be taken into consideration during grain processing. According to Majak et al. [44] coarsely rolled grain caused a reduction in the frequency of bloating in cattle compared to dry-rolled grain.

\section{Prevention and treatment}

What is true for biogas plants is also true for ruminant bloat: prevention is the best medicine [39]. Ruffin [52] stated that no single method of bloat prevention is 
adequate under all circumstances, but there are management practices as well as drugs which can help to minimize the risks. The five most common methods of pasture bloat prevention are pasture management and grazing control, feeding of roughage supplements, and the administration of antibacterial and anti-foaming agents [37]. Pasture management involves the use of grass or silage-legume mixtures, appropriate fertilization methods, consideration of crop maturity and choice of forage with low bloat potential. Feeding ruminants with dry hay before or during grazing as well as slow adaptation to bloat risk pastures is one of the safest bloat prevention methods $[39,41]$. Ruminants bloat most readily on legume pasture but also when they feed on rape, cabbage leaves, and other succulent crops [41]. The list of forage with low bloat risk includes sainfoin (Onobrychis viciifolia), birdsfoot trefoil (Lotus corniculatus L.), crown vetch (Coronilla varia L.), cicer milkvetch (Astragalus cicer L.), and dock (Rumex obtusifolius) [40,53]. Interestingly, all of these bloat-safe plants contain tannins as biological active substances [53]. Tannins are polyphenolic compounds which are of two distinct types: hydrolyzable tannins and condensed tannins (also called proanthocyanidins) [54]. The latter are able to bind and precipitate soluble proteins. Moreover, they also combine with other natural polymers such as cellulose, hemicellulose, pectin, and minerals [54]. Tannins can impair the digestive process by complexing with secreted enzymes and endogenous protein and, thus, inhibiting the activity of rumen microbes $[37,44,54]$. On the other hand, proanthocyanidins in moderate concentrations ( $2 \%$ to $4 \%$ DM) can exert a beneficial effect on the protein metabolism in ruminant organisms by slowing the degradation of dietary protein to ammonia in the rumen and by increasing the protein outflow from the rumen resulting in an increase of amino acid adsorption in the small intestine of the animal [43].

Thus, the next most effective and at the same time cheapest method of preventing pasture bloat is to seed pastures using mixtures of legumes and tannin-containing plants. Moreover, it has long been known that mixing legumes with weed and grasses (making up at least $50 \%$ of the mixture) can minimize the bloat risk of a pasture $[37,41]$. On top of that, continuous grazing regimes lower the incidence of bloat compared to interrupted grazing cycles which are connected with intensive forage ingestion [55].

In the case of feedlot bloat, an immediate reduction or elimination of bloat sources, such as beet pulp or molasses, can help to control bloat efficiently [44]. As bloat occurs mainly during the finishing period (i.e., after changing from pasture to feedlot), a sufficient time of 14 to 21 days has to be planned for rumen microorganisms to adapt to the new conditions. During this time, transition diets with a stepwise increase of the grain proportion are recommended
[40]. Grain processing has to be optimized so that the intake of large amounts of rapidly fermentable fine-grain particles is prevented; the most recommendable way of grain processing in this context is streamrolling [40]. On the other hand, increasing the grain particle size can lead to a decrease in feed efficiency and, thus, has a negative impact on production costs [40]. Therefore, an optimum grain size has to be found in order to operate economically. Moreover, if animals are on a high grain diet, physical fiber such as grass hay or cereal silage has to be added at increased levels [40].

If an animal already bloats, it has to be cured. Yami and Zewdie [39] described some traditional methods for the treatment of bloat, such as keeping the animal in standing position, applying lifting pressure to the side of the stomach, and making the animal salivate by tying a smooth stick crosswise in the mouth. If the animal shows signs of improvement, it should be put on dry, coarse hay.

As bloat is a problem of foaming, anti-foaming agents can be used just like in biogas plants [37]. Apart from plant, animal, and mineral oils, various detergents are available in the market (e.g., ionophores such as monensin, lasalocid, and pluronic detergents) [40]. The antifoaming agent can be applied as feed additives or, under acute circumstances, can be inserted through a stomach tube. Yami and Zewdie [39] also recommended using a water solution of sodium bicarbonate (cooking or baking soda) that should help to disperse the gas; Wang et al. [40] reported on bloat control by the addition of common salt $(40 \mathrm{~g} / \mathrm{kg})$ to the diet. Clarke and Reid [37] discussed the application of antibiotics in the case of bloat as reducing agents for microbial activity in the rumen. Mainly Gram-positive bacteria are inhibited by the use of antibiotics [40]. However, antibiotics are very rarely fully effective under bloat-inducing conditions [40].

Although many risk factors for both pasture and feedlot bloat have been identified and several theories about foam formation in the rumen have been established, the understanding of the fundamental microbial processes involved in bloat etiology remains vague [40] so that as in this area of research some questions still remain to be answered.

\section{Advantages of the rumen as a natural system compared to a biogas plant}

Contrary to fermenters of biogas plants, the microbiota of the rumen of ruminants is influenced by saliva containing enzymes, antibodies, acute phase proteins, hormones, salts, etc. The immune system with its native and acquired fraction is the second barrier to stabilize the microbial homoeostasis in the gastrointestinal tract of ruminants.

The microbiota of the rumen is influenced by many external and internal factors. The immune system is able 
to regulate the microbiota, which is influenced by food. In particular, the quality and quantity of forage have an impact on the amount and composition of microbiota (M Krüger, personal communication). Just as in biogas plants, a steady and adapted $\mathrm{pH}$ value is necessary for the regular functioning of the bovine intestine. As the $\mathrm{pH}$ value is measured by organic sensors, the saliva with its carbonate and phosphatic buffers, minerals, micronutrients, diverse proteins, and enzymes is able to adjust or alter the parameters of the rumen contents, which have a significant impact on the regular metabolic and microbial activity in the rumen [56]. The saliva contains immunoglobulins secreted by immunocells and proteins such as mucines, lysocymes, lactoferrin, and histatin which influence and regulate microbial growth in the fermentation organ ( $\mathrm{M}$ Krüger, personal communication). Normal activity in the rumen depends on the physiological intake of forage appropriate to the species. In contrast to biogas plants, cows disintegrate forage through repetitive rumination and mixing the mash up with saliva which contains a significant amount of water [56]. All these natural, self-controlled factors ensure a regular eupepsia. As the biogas plant is not equipped with such a complex self-regulating system, the knowledge, mindfulness, and intuition of the human operators of the biogas plant and upset-free process operation are important factors for an effective, ecological, sustainable, and durable operation of biogas plants.

\section{Conclusions}

In conclusion, there are many similarities between the foam formation in a biogas reactor and bloat in cow rumen:

1. Triggering mechanisms: Protein-rich and easily degradable substrates as well as overfeeding are connected with both foaming and bloating. Excessive feeding of finely ground grain leads to foam formation in both biogas plant and rumen.

2. Prevention methods: In order to prevent foam formation in biogas plants and animal rumen, feeding of foam-inducing and foam-stabilizing substrates such as clover, finely ground grain, or beet pulp has to be minimized or even avoided. When feeding conditions are changed, a sufficient time for the adaptation of the fermentative microorganisms has to be allowed in both cases. Continuous substrate/forage supply rather than high amounts in few batches is very important.

3. Treatment methods: In both cases, the 'starvation diet' is a 'first aid' response in the event of excessive foaming. While animals automatically stop the food intake in the event of bloating, the biogas plant operator has to think ahead and minimize or stop the substrate feeding [34]. Also, the application of anti-foaming agents is a common treatment method for both occurrences.

The aim of this review is to provide an overview of the present knowledge on foam formation in biogas plants treating renewable resources and biogenic waste material. In working on this problem, another related and fascinating research area was identified which suggested many new approaches to the search for a solution to the problem of foaming in biogas plants. It is no surprise that there are so many similarities between foaming in biogas reactors and bloat in rumen since both are biological systems which essentially operate according to a comparable principle. However, there are still many questions which have to be answered. For example, why do some digesters react by foaming while others do not foam under the same conditions? What happens in a biogas reactor in the event of an immediate change of the operating conditions (e.g., temperature)? Can tannins be applied as effective antifoaming agents in biogas plants?

Competing interests
The authors declare that they have no competing interests.

\section{Acknowledgments}

The project was kindly funded by the German Federal Ministry for the Environment, Nature Conservation and Nuclear Safety on the basis of a decision of the German Bundestag (03 KB018). Special thanks to Silvia Reimann for her helpful discussions and critical reading of the manuscript.

\section{Author details}

${ }^{1}$ Environmental and Biotechnology Centre, UFZ - Helmholtz Centre for Environmental Research, Permoserstrasse 15, Leipzig 04318, Germany. ${ }^{2}$ Institute of Bacteriology and Mycology, University of Leipzig, An den Tierkliniken 29, Leipzig 04103, Germany.

\section{Authors' contributions}

LM collected and sorted the publication and information material and prepared the manuscript. KG, AZ, and RAM critically read the manuscript and provided input for the final version. JN assisted us with his veterinary knowledge and in writing the manuscript section about ruminant bloat. All authors read and approved the final manuscript.

\section{Dedication}

This publication is dedicated to Prof. Wolfgang Babel on the occasion of his 75th birthday.

Received: 22 June 2012 Accepted: 16 July 2012

Published: 16 July 2012

\section{References}

1. Kuratorium für Technik und Bauwesen in der Landwirtschaft e.V., Kuratorium für Technik und Bauwesen in der Landwirtschaft e.V. (KTBL) (2007) Landwirtschaftliche Biogasanlagen in Deutschland. In: Kuratorium für Technik und Bauwesen in der Landwirstchaft e. V. Faustzahlen Biogas, Darmstadt, pp 9-14

2. German Biogas Association (2011) Fachverband Biogas e. V. Biogas Branchenzahlen. Freising, Germany, http://www.biogas.org/edcom/webfvb. nsf/id/DE Branchenzahlen. Accessed 16 Mar 2012

3. Moeller L, Görsch K, Müller RA, Zehnsdorf A (2012) Bildung von Schaum in Biogasanlagen und seine Bekämpfung - Erfahrungen aus der Praxis. Landtechnik 67(2):108-111

4. Schumann W, Gurgel A (2007) Schwachstellenanalyse an ausgewählten Biogasanlagen in Mecklenburg-Vorpommern. In: Abstracts of 1. Rostocker 
Bioenergieforum. Universität Rostock, Bioenergieland MecklenburgVorpommern, pp 24-25

5. Pujol R, Duchene P, Schetrite S, Canler JP (1991) Biological foams in activated sludge plants: characterization and situation. Wat Res 25 : 1399-1404

6. Ross RD, Ellis L-AM (1992) Laboratory-scale investigation of foaming in anaerobic digesters. WER 62:154-162

7. Pagilla KR, Craney KC, Kido WH (1997) Causes and effects of foaming in anaerobic sludge digesters. Wat Sci Tech 36:463-470

8. Westlund ÅD, Hagland E, Rothman M (1998) Foaming in anaerobic digesters caused by Microthrix parvicella. Wat Sci Tech 37:51-55

9. Westlund ÅD, Hagland E, Rothman M (1998) Operational aspects on foaming in digesters caused by Microthrix parvicella. Wat Sci Tech 38:29-34

10. Barjenbruch M, Hoffmann $H$, Kopplow O, Tränckner J (2000) Minimizing of foaming in digesters by pre-treatment of the surplus-sludge. Wat Sci Tech 42:235-241

11. Lemmer H, Lind G (eds) (2000) Blähschlamm, Schaum, Schwimmschlamm. Mikrobiologie und Gegenmaßnahmen. F. Hirthammer Verlag, München

12. Kopplow U (2006) Maßnahmen zur Minderung des Schäumens im Faulbehälter unter besonderer Berücksichtigung der Klärschlammdesintegration. Dissertation, Universität Rostock

13. Ganidi N, Tyrrel S, Cartmell E (2009) Anaerobic digestion foaming causes - a review. Bioresource Technol 100:5546-5554

14. Ganidi N, Tyrrel S, Cartmell E (2011) The effect of organic loading rate on foam initiation during mesophilic anaerobic digestion of municipal wastewater sludge. Bioresource Technol 102:6637-6643

15. Mollet H, Grubenmann A (eds) (2000) Formulierungstechnik. Weinheim, Wiley-VCH Verlag GmbH

16. Pelton R (2002) A review of antifoam mechanisms in fermentation. J Ind Microbiol Biotechnol 29:149-154

17. Vardar-Sukan F (1998) Foaming: consequences, prevention and destruction. Biotechnol Adv 16:913-948

18. Saharan BS, Rahu RK, Sharma D (2011) A review on biosurfactants: fermentation, current developments and perspectives. Genet Eng Biotechnol J :GEBJ-29

19. Ward AJ, Hobbs PJ, Holliman PJ, Jones DL (2008) Optimization of the anaerobic digestion of agricultural resources. Bioresource Technol 99: 7928-7940

20. Switzenbaum MS, Giraldo-Gomez E, Hickey RF (1990) Monitoring of the anaerobic methane fermentation process. Enzyme Microb Technol 12: 722-730

21. Borcherding K (2004) Untersuchungen zur Charakterisierung der Makro- und Mikrostruktur von Milchschäumen. Christian-Albrechts-Universität zu Kiel, Dissertation

22. Dohányos M (2008) Zvyšování efektivity fermentace - nejnovější poznatky ve výzkumu a praxi. Paper presented at 4th conference. Biomasa \& Bioplyn, b.i.d. servis s.r.o, Prague, pp 5-6

23. Eder B, Schulz H (2007) Der Biogas-Prozess, in Biogas Praxis, 4th edn. Ökobuch Verlag, Freiburg, pp 19-40

24. Chen Y, Cheng JJ, Creamer KS (2008) Inhibition of anaerobic digestion process: a review. Bioresource Technol 99:4044-4064

25. Baserga U (2000) Vergärung organischer Reststoffe in landwirtschaftlichen Biogasanlagen. FAT-Berichte 546:1-9

26. Knol W, van der Most MM, de Waart J (1978) Biogas production by anaerobic digestion of fruit and vegetable waste. A preliminary study. J Sci Fd Agric 29:822-830

27. Meuser F, Busch KG, Fuhrmeister H, Rubach K (2001) Foam-forming capacity of substances present in rye. Cereal Chem 78:50-54

28. Zehle F (2009) Die Entstehung von Schaumstrukturen in Backwaren und deren Vorprodukten. Informationsmaterial der IGV GmbH zur iba. http://www.igv-gmbh.de/aktuelles/projekte/entstehungvonschaumstrukturen-in-backwaren.html. Accessed 15 Feb 2012

29. Oelsner E (2007) Vergärung von Gülle und Hühnermist in der Mörsodorfer Agrar GmbH. In: Biogas im Wandel, 16th annual conference of Fachverband Biogas., Leipzig

30. Effenberger M, Lebuhn M, Gronauer A (2007) Biogas im Wandel, 16th annual conference of Fachverband Biogas. In: Fermentermanagement: Stabiler Prozess bei NawaRo-Anlagen., Leipzig

31. Bayrische Landesanstalt für Landwirtschaft (2006) Biogastechnologie zur umweltverträglichen Flüssigmistverwertung und Energiegewinnung in
Wasserschutzgebieten. LfL-Schriftenreihe 23/2006. Bayerische Landesanstalt für Landwirtschaft, Freising-Weihenstephan

32. Wetter C, Brügging E (2004) Leitfaden zum Bau einer Biogasanlage, ed. Fachhochschule Münster, Vol 4. Umweltamt des Kreises Steinfurt, Münster

33. Moeller L, Herbes C, Müller RA, Zehnsdorf A (2010) Schaumbildung und -bekämpfung im Prozess der anaeroben Gärung. Landtechnik 65 : 204-207

34. Baumann T (2005) Du sollst... Die 13 Biogas-Gebote. DLZ 4:26-31

35. Neis U (2005) Bekämpfung von Bläh- und Schwimmschlamm mit Ultraschall. In: Neis U (ed) Ultraschall in der Umwelttechnik - III. Hamburger Berichte zur Siedlungswasserwirtschaft, GFEU, TU Hamburg-Harburg

36. Hofmann R (2003) Einsatz von Kemwater-Entschäumern besänftigt schlaflose Mitarbeiter. Der Kemwaterspiegel - Das Magazin für Wasseraufbereitung von Kemira Kemwater, p 5

37. Clarke RTJ, Reid CSW (1974) Foamy bloat of cattle. A review. J Dairy Sc 57:753-785

38. Cole HH, Huffmann CF, Kleiber M, Olson TM, Schalk AF (1945) A review of bloat in ruminants. J Anim Sci 4:183-236

39. Yami A, Zewdie S (2009) Bloat in sheep and goats: causes, prevention and treatment. In: Merkel RC, Dawson L (eds) Technical bulletin No. 31, Ethiopia sheep and goat productivity improvement program (ESGPIP). ESGPIP, Addis Ababa, pp 1-9

40. Wang Y, Majak W, McAllister T (2012) Frothy bloat in ruminants: cause, occurrence, and mitigation strategies. Anim Feed Sci Technol 172:103-114

41. Cole HH, Amadon RS, Doughetty RW, Espe D, Huffmann CG, Olson TM, Schalk AF (1943) Bloat in cattle and sheep. Recommendations for prevention. Canadial J Comp Med VII(9):273-275

42. Harris PJ, Sebba F (1965) Possible relationship between trace metals and bloat in ruminants. Nature 208:869-871

43. Aerts RJ, Barry TN, McNabb WC (1999) Polyphenols and agriculture: beneficial effects of proanthocyanidins in forages. Agricult Ecosys Environ 75:1-12

44. Majak W, McAllister TA, McCartney D, Stanford K, Cheng K-J (2003) Bloat in cattle. Alberta Agriculture and Rural Development, Canada

45. Colvin HW Jr, Backus RC (1988) Bloat in sheep (Ovis aries). Mini Review Comp Biochem Physiol 91A:635-644

46. Head MJ (1959) Bloat in cattle. Nature 183:757

47. Hall JW, Majak W (1989) Plant and animal factors in legume bloat. In: Cheeke PR (ed) Toxicants of plant origin, Vol 3, Proteins and amino acids. CRC Press, Boca Raton, FL, USA, pp 93-106

48. Howarth RE, Majak W, Waldern DE, Brandt SA, Fesser AC, Goplen BP, Spurr DT (1977) Relationships between ruminant bloat and the chemical composition of alfalfa herbage. I Nitrogen and protein fractions. Can J Anim Sci 57:345-357

49. Howarth RE, Cheng K-J, Majak W, Costerston JW (1986) Ruminant bloat. In: Milligan LP, Grovum WL, Dobson A (eds) Control of digestion and metabolism in ruminants. Prentice-Hall, Englewood Cliffs, NJ, USA, pp 516-527

50. Velisek J (1999) Voda. In: Velisek J (ed) Chemie potravin 2. Ossis, Tábor, pp 110-153

51. Lindahl IL, Cook AC, Davis RE, Maclay WD (1954) Preliminary investigations on the role of alfalfa saponin in ruminant bloat. Science 119:157-158

52. Ruffin BG (1994) Controlling bloat in cattle. Alabama Cooperative Extension System ANR-148, AL, USA

53. Rochfort S, Parker AJ, Dunshea FR (2008) Plant bioactives for ruminant health and productivity. Review Phytochemistry 69:299-322

54. McSweeney CS, Palmer B, McNeill DM, Krause DO (2001) Microbial interactions with tannins: nutritional consequences for ruminants. Anim Feed Sci Technol 91:83-93

55. Majak W, Hall JW, Mc Caughey WP (1995) Pasture management strategies for reducing the risk of legume bloat in cattle. J Anim Sci 73:1493-1498

56. Breves G (2005) Nahrungsaufnahme und Speichelsekretion. In: Engelhardt WV (ed) Physiologie der Haustiere, 2nd edn. Enke Verlag, Stuttgart, pp 332-337

doi:10.1186/2192-0567-2-12

Cite this article as: Moeller et al: Comparative review of foam formation in biogas plants and ruminant bloat. Energy, Sustainability and Society 2012 2:12. 